WAHANA

AKUNTANSI

Jumalliknis
JURNAL ILMIAH WAHANA AKUNTANSI

Vol 13 (2) 2018, 95-109

http://journal.unj.ac.id/unj/index.php/wahana-akuntansi

\title{
PERAN KOMISARIS INDEPENDEN DALAM MEMODERASI DETERMINAN PENGUNGKAPAN MODAL INTELEKTUAL
}

Sofi Amanatun Khasanah*

Asrori

(Universitas Negeri Semarang)

\begin{tabular}{l}
\hline Article Info \\
\hline Keywords: \\
Firm Size; Independent Commissioner; \\
Intellectual Capital Disclosure; Intellectual \\
Capital Level
\end{tabular}

Capital Level

\begin{abstract}
The purpose of this research is to analyze the effect of firm size and intellectual capital level on intellectual capital disclosure with independent commissioners as a moderating variable. The population in this research are 42 banking companies listed in Indonesia Stock Exchange (IDX) period 20142016. Samples are selection using purposive sampling technique and obtained 102 units of analysis as observations' object. This research analysis technique used moderation regression analysis by difference absolute value test was used to analyze data. The results of this research indicates that the firm size have a significant positive effect on intellectual capital disclosure. Intellectual capital level does not affect the intellectual capital disclosure. Independent commissioners moderate significantly the effect of firm size on intellectual capital disclosure but in negative way and moderate positively significant intellectual capital level on intellectual capital disclosure. Conclusion from this research that intellectual capital disclosure is influenced by firm size and is not influenced by intellectual capital level. Independent commissioner can moderate the effect of firm size and intellectual capital level on intellectual capital disclosure.
\end{abstract}

\begin{abstract}
Abstrak
Tujuan penelitian ini adalah menganalisis pengaruh variabel ukuran perusahaan dan tingkat modal intelektual terhadap pengungkapan modal intelektual dengan komisaris independen sebagai variabel moderating. Populasi dalam penelitian ini yaitu 42 perusahaan perbankan yang terdaftar di Bursa Efek Indonesia (BEI) periode 2014-2016. Sampel dipilih dengan menggunakan teknik purposive sampling dan diperoleh 102 unit analisis yang menjadi objek penelitian. Teknik analisis yang digunakan dalam penelitian ini menggunakan analisis regresi moderasi dengan uji nilai selisih mutlak. Hasil penelitian ini menunjukkan bahwa ukuran perusahaan berpengaruh positif signifikan terhadap pengungkapan modal intelektual. Tingkat modal intelektual tidak berpengaruh terhadap pengungkapan modal intelektual. Komisaris independen memoderasi secara signifikan pengaruh ukuran perusahaan terhadap pengungkapan modal intelektual namun dengan arah negatif dan memoderasi secara positif signifikan tingkat modal intelektual terhadap pengungkapan modal intelektual. Simpulan dari penelitian ini yaitu pengungkapan modal intelektual dipengaruhi oleh ukuran perusahaan dan tidak dipengaruhi oleh tingkat modal intelektual. Komisaris independen mampu memoderasi pengaruh ukuran perusahaan dan tingkat modal intelektual terhadap pengungkapan modal intelektual.
\end{abstract}

\section{How to Cite:}

Khasanah, Sofi Amanatun Khasanah dan Asrori. (2018). Peran Komisaris Independen dalam Memoderasi Determinan Pengungkapan Modal Intelektual. Jurnal Ilmiah Wahana Akuntansi, 13(2), 95-109. https://doi.org/10.21009/wahana.013.2.1

\footnotetext{
* Corresponding Author: 


\section{PENDAHULUAN}

Persaingan bisnis yang terjadi saat ini membuat setiap perusahaan harus melakukan perencanaan strategi yang baik dan tepat untuk meningkatkan kinerja agar tujuan perusahaan dapat tercapai. Para pelaku bisnis mulai menyadari bahwa kemampuan bersaing tidak hanya terletak pada kepemilikan aktiva berwujud saja, akan tetapi lebih pada inovasi, teknologi, sistem informasi, pengelolaan organisasi dan sumber daya manusia yang dimilikinya. Oleh karena itu, pentingnya knowledge asset (aset pengetahuan) sebagai salah satu aset tidak berwujud menjadikan perusahaan-perusahaan akan terus bertahan dengan cara mengubah bisnis yang didasarkan pada tenaga kerja (labor-bassed business) menuju bisnis berdasarkan pengetahuan

(knowledge based business), dengan karakteristik utama yaitu ilmu pengetahuan (Suwarjuwono \& Kadir, 2003).

Salah satu pendekatan yang digunakan dalam penilaian dan pengukuran knowledge asset (aset pengetahuan) adalah modal intelektual (intellectual capital) (Petty \& Guthrie, 2000). Implementasi modal intelektual merupakan hal yang masih baru, bukan hanya di Indonesia saja tetapi juga di lingkup global. Kalangan bisnis pada umumnya belum menemukan jawaban yang tepat mengenai nilai lebih apa yang seharusnya dimiliki oleh perusahaan. Nilai lebih tersebut dihasilkan oleh modal intelektual yang dapat diperoleh dari budaya pengembangan perusahaan maupun kemampuan perusahaan dalam memotivasi karyawannya sehingga produktivitas perusahaan dapat bertahan atau bahkan mengalami peningkatan (Suwarjuwono \& Kadir, 2003).

Benevene et al. (2017) menyatakan bahwa terdapat tiga fase utama dalam modal intelektual. Pertama, pada tahun 1990an studi terkait modal intelektual ditujukkan terutama untuk mengidentifikasi komponen dan peran modal intelektual dalam mengembangkan nilai pasar perusahaan. Kedua, modal intelektual perlu ditegaskan dengan jelas, sehingga pada tahap ini sejumlah pendekatan dikembangkan untuk menilai dan mengungkapkan modal intelektual. Ketiga, dimulai pada awal 2000an bahwa terdapat kesulitan dalam menggambarkan dan menentukan nilai modal intelektual dalam bentuk angka. Hal tersebut mengingat bahwa modal intelektual merupakan sumber daya yang tidak berwujud sehingga pendekatan narasi yang lebih rinci kemudian dianggap lebih tepat untuk menangani modal intelektual (Bronzetti \& Veltri, 2013). Selama ini modal intelektual dapat diketahui oleh stakeholder melalui laporan tahunan perusahaan yang dipublikasikan. Hal tersebut menjadi salah satu alasan pelaku bisnis dalam pengambilan keputusan.

Permasalahan utama yang timbul adalah bahwa pentingnya modal intelektual tidak searah dengan luas informasi modal intelektual yang diungkapkan perusahaan (Setianto \& Purwanto, 2014). Padahal kurangnya pengungkapan modal intelektual akan mengakibatkan informasi yang disampaikan menjadi tidak jelas dan tidak bermanfaat (Setianto \& Purwanto, 2014). 
Konsekuensi dari pengungkapan modal intelektual akan terjadi peningkatan asimetri informasi antara perusahaan dengan pengguna laporan keuangan (Bruggen et al., 2009). Peningkatan asimetri informasi tersebut pada akhirnya dapat mengakibatkan keputusan yang diambil stakeholders menjadi kurang tepat (Setianto \& Purwanto, 2014).

Informasi mengenai intellectual capital semakin penting bagi pihak internal maupun pihak eksternal perusahaan karena dalam kurun waktu beberapa tahun kebelakang terlihat beberapa perusahaan mulai mengambil

kebijaksanaan untuk melakukan dan memperluas jangkauan pengungkapan modal intelektual (Zulkarnaen \& Mahmud, 2013). Pengungkaan modal intelektual merupakan cerminan banyaknya informasi terkait dengan knowledge asset (aset pengetahuan) yang terdapat dalam laporan tahunan perusahaan. Hasil survei global menunjukkan bahwa modal intelektual merupakan salah satu tipe informasi yang paling banyak dipertimbangkan oleh investor. Dengan demikian, masih ada "information gap" (Bozzolan et al., 2003). Berikut disajikan ringkasan hasil rata-rata pengungkapan modal intelektual yang dilakukan oleh peneliti terdahulu dengan berbagai objek penelitian.

Data terkait rata-rata pengungkapan modal intelektual yang dilakukan oleh Cahya (2014) pada perusahaan perbankan pada tahun 2009-2011 sebanyak 34,93\%. Nugroho (2012) yang melakukan penelitian pada perusahaan manufaktur pada tahun 2010 menghasilkan rata-rata pengungkapan sebanyak 26,79\%.

Penelitian Setianto \& Purwanto (2014) menunjukkan rata-rata pengungkapan sebesar 25,16\% pada indeks kompas 100 pada tahun penelitian 2010-2012. Berdasarkan data tersebut menunjukkan bahwa hasil rata-rata pengungkapan modal intelektual di Indonesia masih cukup rendah jika dibandingkan dengan penelitian yang dilakukan oleh Yi \& Davey (2010) pada seluruh perusahaan yang terdapat di Cina termasuk sektor perbankan. Hasil ratarata pengungkapan modal intelektual pada Industrial and Commercial Bank of China Ltd., China Merchants Bank Co. Ltd. dan Bank of China Ltd. masing-masing sebesar 65\%, 57\% dan 55\%. Hal tersebut membuktikan bahwa jika dibandingkan dengan pengungkapan modal intelektual pada perusahaan perbankan di Cina, hasil rata-rata pengungkapan modal intelektual di Indonesia masih rendah.

Peneliti tertarik menggunakan perusahaan perbankan yang terdaftar di Bursa Efek Indonesia (BEI) karena secara umum sektor perbankan merupakan sektor yang ideal untuk penelitian intellectual capital (Kamath, 2007). Menurut Firer \& Williams (2003), sektor perbankan merupakan sektor industri yang memiliki insentif modal intelektual tinggi. Selain itu, dari aspek intelektual, secara keseluruhan karyawan (human capital) di sektor perbankan lebih homogen dibandingkan dengan sektor ekonomi lainnya (Kubo \& Saka, 2002). Lebih lanjut, Kamath (2007) menjelaskan 
bahwa sektor perbankan memiliki data terpercaya dalam bentuk akun yang dipublikasikan dalam laporan tahunan. Data terpercaya yang dimaksud dalam hal ini yaitu terkait dengan modal intelektual yang dimiliki oleh perusahaan perbankan tersebut.

Penelitian yang dilakukan oleh Ferreira et al. (2012) dan Oktavianti (2014) menemukan bahwa ukuran perusahaan berpengaruh positif signifikan terhadap pengungkapan modal intelektual. Sementara penelitian dari Nugroho (2012) menunjukkan hasil yang sebaliknya, yaitu ukuran perusahaan tidak berpengaruh terhadap pengungkapan modal intelektual. Ferreira et al. (2012) dan Setianto \& Purwanto (2014) menemukan tingkat modal intelektual tidak berpengaruh terhadap pengungkapan modal intelektual. Berbeda dengan penelitian yang dilakukan oleh Utama \& Khafid (2015) yang menemukan bahwa tingkat modal intelektual berpengaruh negatif terhadap pengungkapan modal intelektual. Penelitian terkait komisaris independen dengan pengungkapan modal intelektual telah dilakukan oleh Nugroho (2012) dan Oktavianti (2014). Hasil penelitian yang diperoleh Nugroho (2012) dan Oktavianti (2014) menunjukkan bahwa komisaris independen tidak berpengaruh terhadap pengungkapan modal intelektual. Berbeda dengan penelitian Ashari dan Putra (2016) yang menyatakan bahwa komisaris independen berpengaruh positif terhadap pengungkapan modal intelektual.

Perbedaan hasil penelitian terdahulu memungkinkan peneliti mengajukan variabel baru dalam penelitian ini, yaitu komisaris independen sebagai variabel moderating. Penggunaan variabel komisaris independen disini diharapkan dapat mempengaruhi hubungan ukuran perusahan dan tingkat modal intelektual terhadap pengungkapan modal intelektual. Sepanjang pengetahuan peneliti penggunaan variabel komisaris independen sebagai variabel moderating terhadap variabel pengungkapan modal intelektual belum pernah dilakukan sebelumnya.

Tujuan dari penelitian ini yaitu untuk mengetahui pengaruh ukuran perusahan dan tingkat modal intelektual terhadap pengungkapan modal intelektual dengan komisaris independen sebagai variabel moderating. Orisinalitas dalam penelitian ini adalah penggunaan variabel komisaris independen sebagai variabel moderating. Alasan ditambahkan komisaris independen sebagai variabel moderating karena komisaris independen adalah untuk memperkuat pengaruh ukuran perusahaan dan tingkat modal intelektual terhadap pengungkapan modal intelektual dan menunjukkan hasil yang konsisten.

Teori yang digunakan untuk menjelaskan hubungan antar variabel dalam penelitian pengungkapan modal intelektual ini adalah agency theory, signalling theory dan stakeholder theory. Teori-teori tersebut menjelaskan hubungan antara manajer perusahaan dengan stakeholder. Agency theory mendefinisikan adanya hubungan keagenan 
antara manajemen perusahaan (agents) dengan pemilik perusahaan (principal). Pemilik perusahaan mendelegasikan kewenangan untuk mengelola perusahaan kepada manajemen perusahaan. Manajemen perusahaaan tidak selalu mematuhi atau bekerja sesuai dengan harapan pemilik perusahaan sehingga terjadilah kesenjangan informasi antara pemilik perusahaan dengan manajemen perusahaan yang menimbulkan biaya agensi. Signalling theory menjelaskan bahwa dengan melakukan pengungkapan yang menyeluruh dapat memberikan sinyal positif atau sinyal baik kepada stakeholder. Stakeholder theory menyatakan bahwa manajemen organisasi diharapkan untuk melakukan aktivitas yang dianggap penting oleh stakeholder mereka dan melaporkan kembali aktivitas-aktivitas tersebut pada stakeholder (Deegan, 2004).

Pemegang saham tentu akan memiliki pengetahuan yang lebih luas tentang kondisi perusahaan, termasuk tentang bagaimana prospek penciptaan nilai perusahaan di masa yang akan datang. Dengan berkurangnya asimetri informasi antara pemegang saham dan manajer, maka biaya keagenan yang dikeluarkan untuk memantau kinerja manajer juga berkurang. Oleh karena itu, untuk mengurangi biaya keagenan, perusahaan yang lebih besar tentu akan termotivasi untuk melakukan pengungkapan modal intelektual secara lebih luas. Agency theory menjelaskan biaya keagenan bertambah seiring dengan bertambahnya proporsi modal eksternal. Sementara penggunaan modal eksternal pada perusahaan besar cenderung semakin besar. Oleh karena itu, perusahaan besar cenderung memiliki biaya keagenan yang lebih tinggi dibandingkan perusahaan kecil. Dengan melakukan pengungkapan modal intelektual secara lebih luas, asimetri informasi antara pemegang saham dan manajer dapat dikurangi.

Sejalan dengan hasil penelitian yang dilakukan oleh Purnomosidhi (2006), Bruggen et al. (2009) dan Ferreira et al. (2012) yang menemukan bahwa terdapat pengaruh positif ukuran perusahaan terhadap pengungkapan modal intelektual. Artinya semakin besar perusahaan maka akan termotivasi untuk mengungkapkan modal intelektual yang lebih guna menarik investor agar menanamkan saham diperusahaan. Oleh karena itu, ukuran perusahaan diyakini berpengaruh positif signifikan terhadap pengungkapan modal intelektual.

\section{$\mathrm{H}_{1}$ : Ukuran perusahaan berpengaruh positif signifikan terhadap pengungkapan modal intelektual}

Pengungkapan yang dilakukan oleh perusahaan pada dasarnya akan dilakukan apabila perusahaan mempunyai sesuatu yang dapat ditonjolkan sebagai keunggulan yang dimilikinya (Saendy dan Anisykurlillah, 2015). Berdasarkan hal tersebut manajemen akan berusaha untuk memperluas informasinya ketika modal intelektual yang dimiliki perusahaan tinggi, sehingga terdapat keunggulan kompetitif yang dapat dijadikan kekuatan untuk bersaing dari suatu perusahaan. 
Teori sinyal menjelaskan perusahaan dengan tingkat modal intelektual yang signifikan cenderung termotivasi untuk mengungkapkan modal intelektual sebagai bentuk pemberian sinyal positif kepada stakeholder (Ferreira et al., 2012). Hal ini dilakukan oleh perusahaan untuk membedakan dengan perusahaan lain yang tingkat modal intelektualnya relatif lebih rendah.

Teori stakeholder menyatakan pemegang saham memiliki hak untuk mendapatkan informasi tentang aktivitas-aktivtas perusahaan, termasuk aktivitas tentang pengelolaan modal intelektual. Asumsi ini didukung oleh penelitian yang dilakukan Kang \& Gray (2011) dan Setianto \& Purwanto (2014) yang menunjukkan tingkat modal intelektual berpengaruh signifikan terhadap pengungkapan modal intelektual. Oleh karena itu, tingkat modal intelektual diyakini berpengaruh positif signifikan terhadap pengungkapan modal intelektual.

\section{$\mathrm{H}_{2}$ : Tingkat modal intelektual berpengaruh positif signifikan terhadap pengungkapan modal intelektual}

Komisaris independen merupakan salah satu mekanisme corporate governance yang diperlukan untuk mengurangi agency problem antara pemilik dan manager sehingga menimbulkan keselarasan kepentingan antara pemilik perusahaan dan manager. Adanya keselarasan kepentingan tersebut maka diharapkan tidak menimbulkan agency cost .
Menurut teori agensi, kehadiran komisaris independen dapat mengurangi agency cost yang timbul akibat adanya benturan kepentingan antara pihak manajer dengan pemilik modal. Komisaris independen sebagai pihak yang independen diharapkan dapat memberi masukan atau nasehat kepada manager untuk mengungkapkan informasi modal intelektual yang dibutuhkan oleh pemilik modal di laporan keuangan perusahaan. Jumlah komisaris independen bertambah seiring dengan ukuran perusahaan yang semakin meningkat, sehingga tingkat pengungkapan modal intelektual pada perusahaan besar akan lebih tinggi. Berdasarkan asumsi tersebut, komisaris independen diyakini dapat memoderasi positif signifikan pengaruh ukuran perusahaan terhadap pengungkapan modal intelektual.

\section{$\mathrm{H}_{3}$ : Komisaris independen berpengaruh positif signifikan dalam memoderasi pengaruh ukuran perusahaan terhadap pengungkapan modal intelektual.}

Komisaris independen dapat mempengaruhi hubungan antara tingkat modal intelektual dengan pengungkapan modal intelektual. Hubungan ini didukung oleh teori sinyal dan teori stakeholder. Menurut teori sinyal, perusahaan dengan tingkat modal

intelektual yang signifikan cenderung termotivasi untuk mengungkapkan modal intelektual sebagai bentuk pemberian sinyal positif kepada stakeholder (Ferreira et al., 2012). Hubungan tersebut akan diperkuat 
dengan adanya komisaris independen sebagai pihak yang mengawasi pelaksanaan manajemen perusahaan.

Teori stakeholder menyatakan pemegang saham memiliki hak untuk mendapatkan informasi tentang aktivitas-aktivtas perusahaan, termasuk aktivitas tentang pengelolaan modal intelektual. Dengan demikian, perusahaan dengan tingkat modal intelektualnya cukup signifikan akan termotivasi untuk melakukan pengungkapan modal intelektualnya secara lebih luas untuk memuaskan kepentingan pemegang saham dan stakeholders lainnya. Pengungkapan tingkat modal intelektual yang dilakukan oleh perusahaan tidak lepas dari pengaruh komisaris independen dimana kinerja manajer suatu perusahaan akan selalu diawasi oleh pihak komisaris independen, selaku wakil dari pemegang saham. Oleh karena itu, komisaris independen diyakini mampu memoderasi positif signifikan pengaruh tingkat modal intelektual terhadap pengungkapan modal intelektual.

$\mathrm{H}_{4}$ : Komisaris independen berpengaruh positif signifikan dalam memoderasi pengaruh tingkat modal intelektual terhadap pengungkapan modal intelektual.

\section{METODE PENELITIAN}

Penelitian ini adalah penelitian kuantitatif dengan jenis data yang digunakan yaitu data sekunder. Populasi penelitian ini sebanyak 42 populasi perusahaan perbankan yang terdaftar di Bursa Efek Indonesia tahun
2014-2016. Teknik sampling yang digunakan adalah purposive sampling, yaitu teknik pengambilan sampel dengan menggunakan kriteria-kriteria atau pertimbangan tertentu. Penelitian ini diperoleh sampel sebanyak 34 perusahaan dengan tahun pengamatan selama tiga tahun, sehingga dapat diketahui jumlah unit analisis sebanyak 102.

Tabel 1 di bawah ini merupakan proses pengambilan sampel dari penelitian ini. Berdasarkan hasil Tabel 1 diperoleh 102 jumlah perusahaan yang akan menjadi uni analisis dalam penelitian ini. Sedangkan Tabel 2 merupakan definisi operasional masing-masing variabel.

\section{Tabel 1}

Detail Pengambilan Sampel

\begin{tabular}{|c|l|c|}
\hline No & \multicolumn{1}{|c|}{ Kriteria } & $\begin{array}{c}\text { Jumlah } \\
\text { Perusahaan }\end{array}$ \\
\hline 1 & $\begin{array}{l}\text { Perusahaan perbankan } \\
\text { yang terdaftar di BEI } \\
\text { periode tahun 2014-2016 }\end{array}$ & 42 \\
\hline 2 & $\begin{array}{l}\text { Perusahaan perbankan } \\
\text { yang tidak } \\
\text { mempublikasikan laporan } \\
\text { keuangan secara berturut- } \\
\text { turut di web BEI periode } \\
\text { tahun 2014-2016 }\end{array}$ & $(6)$ \\
\hline 3 & $\begin{array}{l}\text { Perusahaan yang tidak } \\
\text { memiliki data terkait } \\
\text { dengan variabel-variabel } \\
\text { yang digunakan dalam } \\
\text { penelitian }\end{array}$ & $(2)$ \\
\hline 4 & $\begin{array}{l}\text { Jumlah sampel penelitian } \\
\text { dalam setahun }\end{array}$ & 34 \\
\hline 5 & \begin{tabular}{l} 
Tahun pengamatan \\
\hline
\end{tabular} & Jumlah unit analisis \\
\hline
\end{tabular}

Sumber: Data Diolah Penulis, Tahun 2018 
Tabel 2

\section{Definisi Operasional}

\begin{tabular}{|c|c|c|c|}
\hline No & VARIABEL & DEFINISI & PENGUIKURAN \\
\hline 1 & 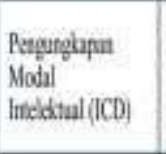 & 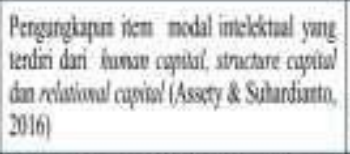 & 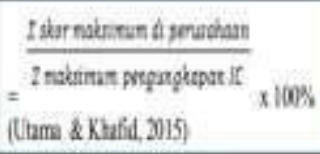 \\
\hline 2 & $\begin{array}{l}\text { Uhum persasiun } \\
\text { (IIII) }\end{array}$ & 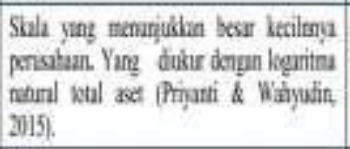 & 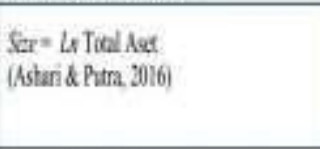 \\
\hline 3 & $\begin{array}{l}\text { Tinelat Modd } \\
\text { limedctal (TMI) }\end{array}$ & 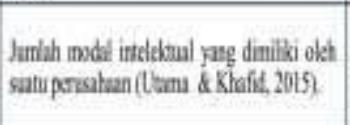 & 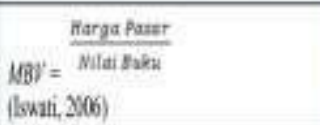 \\
\hline 4 & $\begin{array}{l}\text { Kemisaris } \\
\text { Intepenten } \\
\text { (NDE?) }\end{array}$ & 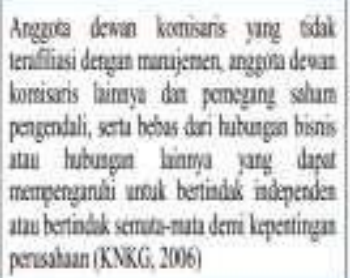 & 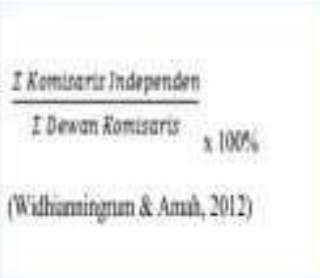 \\
\hline
\end{tabular}

Sumber: Data Diolah Penulis, Tahun 2018

Teknik pengumpulan data dilakukan dengan menggunakan teknik dokumentasi atas laporan tahunan dari website resmi Bursa Efek Indonesia (www.idx.co.id). Teknik analisis yang digunakan adalah analisis statistik deskriptif dan analisis statistik inferensial dengan melakukan uji asumsi klasik dan analisis regresi moderasi dengan menggunakan uji nilai selisih mutlak. Model matematis yang digunakan dalam penelitian ini adalah sebagai berikut:

$$
\mathrm{ICD}=\mathrm{a}+\beta_{1} \mathrm{SIZE}+\beta_{2} \mathrm{TMI}+\beta_{3} \text { ISIZE }
$$

$-\operatorname{INDEP}\left|+\beta_{4}\right|$ TMI - INDEP $\mid+\mathrm{e}$

\section{HASIL DAN PEMBAHASAN}

Analisis statistik deskriptif menggambarkan nilai minimum, maksimum, mean dan nilai standar deviasi untuk setiap variabel dalam penelitian ini. Tabel 3 di bawah ini menunjukkan statistik deskriptif masing-masing variabel dalam penelitian.

\section{Tabel 3}

\section{Statistik Deskriptif}

Descriptive Statistics

\begin{tabular}{|l|r|r|r|r|r|}
\hline & N & \multicolumn{1}{|c|}{ Minimum } & \multicolumn{1}{c|}{ Maximum } & \multicolumn{1}{c|}{ Mean } & Std. Deriation \\
\hline ICD & 102 & 36,07 & 80,33 & 59,4856 & 8,88226 \\
\hline Size & 102 & 28,13 & 34,15 & 30,4481 & 1,54212 \\
\hline TMI & 102 & 0,09 & 4,18 & 1,3095 & 0,81358 \\
\hline NDEP & 102 & 40,00 & 75,00 & 58,1408 & 8,73166 \\
\hline Valid N (lisuisc) & 102 & & & & \\
\hline
\end{tabular}

Sumber: Data Diolah Penulis, Tahun 2018

Tabel 3 di atas menunjukkan bahwa ratarata pengungkapan modal intelektual pada perusahaan perbankan periode 2014-2016 cukup tinggi, yaitu sebesar 59,95\%.

Uji asumsi klasik meliputi uji normalitas dengan uji Kolmogorov-Smirnov menunjukkan nilai Asymp. Sig (2-tailed) 0,086>0,05, uji multikolonieritas dengan nilai Tolerance $>0,1$ $(\mathrm{SIZE}=0,803$; TMI=0,994; INDEP=0,808) dan $\mathrm{VIF}<10 \quad(\mathrm{SIZE}=1,245 ; \quad \mathrm{TMI}=1,006$; INDEP=1,238), uji heteroskedastisitas dengan uji Glejser menunjukkan semua variabel memiliki nilai Sig. $>0,05 \quad$ (SIZE=0,430; TMI=1,154; INDEP=0,300) dan uji autokorelasi dengan uji Durbin-Watson menunjukkan nilai Durbin-Watson 1,777>0,05. Nilai DW dibandingkan dengan nilai dU dan $4-\mathrm{dU}$ adalah $1,7383 \leq 1,777 \leq 2,2617$. Berdasarkan keempat uji asumsi klasik yang telah dilakukan, maka dapat disimpulkan bahwa data dalam penelitian ini telah bebas dari penyimpangan dengan kata lain uji asumsi klasik telah terpenuhi. 
Nilai koefisien determinasi atau Adjusted $R^{2}$ menunjukkan hasil 0,436 yang menunjukkan bahwa model penelitian mampu menjelaskan sebesar $43,6 \%$ variasi dari pengungkapan modal intelektual, sedangkan 56,4\% dijelaskan oleh variabel lain. Hasil pengujian hipotesis dengan tingkat signifikansi $(\alpha=5 \%)$ disajikan pada Tabel 4. Model matematis hasil uji statistik:

$\begin{aligned} \mathrm{ICD}= & 61,177+5,912 \text { ZscoreSIZE }-1,032 \\ & \text { ZscoreTMI }-2,381 \mid \text { ZscoreSIZE }- \\ & \text { ZscoreINDEP }|+2,095 \quad| \text { ZscoreTMI - } \\ & \text { ZscoreINDEP } \mid+\mathrm{e}\end{aligned}$

Tabel 4

\section{Ringkasan Pengujian Hipotesis}

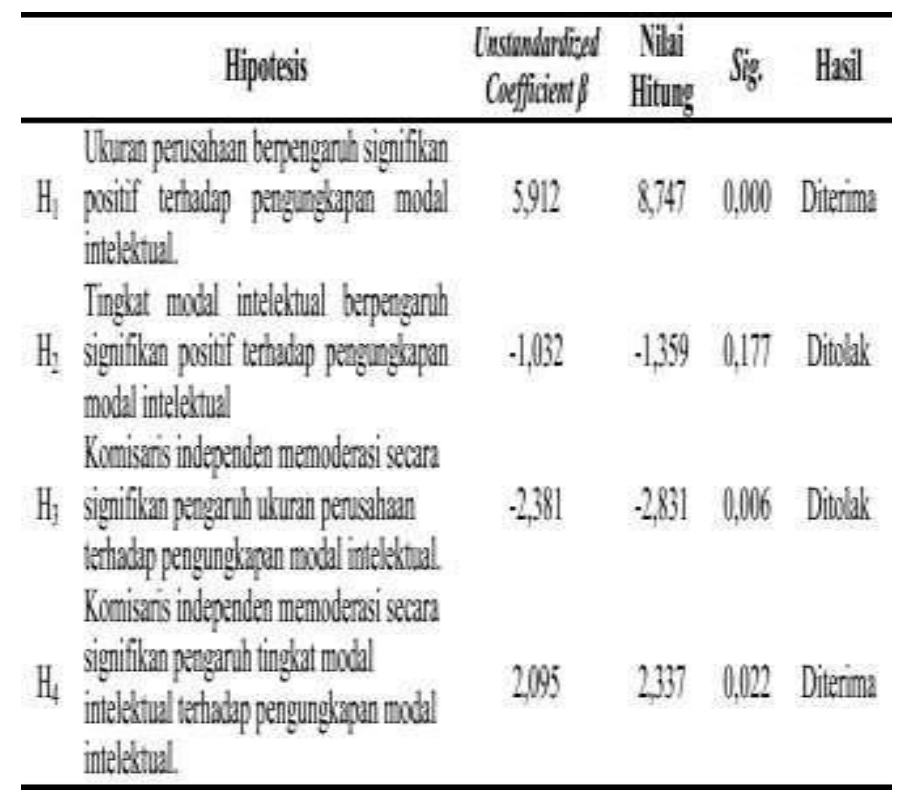

Sumber : Data Diolah Penulis, Tahun 2018

\section{Pengaruh Ukuran Perusahaan terhadap Pengungkapan Modal Intelektual}

Hasil uji hipotesis menunjukkan bahwa ukuran perusahaan memiliki pengaruh positif terhadap pengungkapan modal intelektual.
Sehingga dapat disimpulkan bahwa $\mathrm{H}_{1}$ diterima yang berarti bahwa ukuran perusahaan berpengaruh positif signifikan terhadap pengungkapan modal intelektual. Hasil penelitian ini membuktikan bahwa semakin banyak jumlah aset perusahaan perbankan mengindikasikan bahwa semakin besar pengungkapan modal intelektual yang dilakuakan perusahaan. Oktavianti (2014) mengungkapkan bahwa perusahaan besar merupakan entitas yang banyak disorot oleh pasar maupun publik secara umum. Mengungkapkan lebih banyak informasi merupakan bagian dari upaya perusahaan untuk mewujudkan akuntabilitas publik.

Penelitian tersebut sesuai dengan teori agensi yang menjelaskan hubungan antara pemegang saham dengan manajer. Perbedaan kepentingan menyebabkan terjadinya asimetri informasi antara pemilik dan manajer perusahaan. Perusahaan yang besar memiliki hubungan kompleks yang menimbulkan konflik antara pemilik dan manajer perusahaan sehingga dapat meningkatkan biaya agensi. Semakin besar ukuran suatu perusahaan maka biaya agensi yang dikeluarkan akan semakin meningkat. Berdasarkan hal tersebut dalam rangka mengurangi biaya agensi maka secara sukarela perusahaan mengungkapkan informasi yang ada dalam perusahaan melalui pengungkapan modal intelektual. Dengan demikian, ukuran perusahaan dapat menjadi pendorong bagi perusahaan untuk melakukan pengungkapan modal intelektual. 
Hasil penelitian ini konsisten dengan penelitian yang dilakukan oleh Purnomosidhi (2006), Oktavianti (2014), Ousama et al. (2012) dan Ferreira et al. (2012) yang membuktikan bahwa ukuran perusahaan berpengaruh positif signifikan terhadap pengungkapan modal intelektual. Akan tetapi, penelitian ini tidak sejalan dengan penelitian yang dilakukan oleh Mondal \& Ghosh (2014), Priyanti \& Wahyudin (2015) serta Ashari \& Putra (2016) yang menemukan bahwa ukuran perusahaan tidak berpengaruh terhadap pengungkapan modal intelektual. Menurut Ashari \& Putra (2016) perusahaan besar memang selalu melakukan aktivitas yang lebih banyak dan biasanya memiliki berbagai macam unit usaha yang berpotensi menciptakan nilai jangka panjang yang berbeda, namun hal tersebut tidak selalu membuat perusahaan lebih memiliki kesadaran untuk meningkatkan pengungkapan modal intelektualnya.

\section{Pengaruh Tingkat Modal Intelektual terhadap Pengungkapan Modal Intelektual}

Hasil uji hipotesis menunjukkan bahwa tingkat modal intelektual tidak berpengaruh terhadap pengungkapan modal intelektual. Sehingga dapat disimpulkan bahwa $\mathrm{H}_{2}$ ditolak. Hal tersebut berarti bahwa pengungkapan modal intelektual tidak dipengaruhi oleh jumlah modal intelektual yang dimiliki oleh perusahaan. Hasil penelitian ini tidak sejalan dengan signalling theory karena tidak mampu menjelaskan tentang pengaruh tingkat modal intelektual yang positif signifikan terhadap pengungkapan modal intelektual. Alasan yang mendasari penolakan tersebut karena tingginya modal intelektual yang dimiliki oleh perusahaan belum menjamin peningkatan pengungkapan modal intelektual yang dilakukan oleh suatu perusahaan. Kondisi ini dapat diakibatkan oleh belum adanya peraturan wajib yang mengatur pengungkapan modal intelektual perusahaan dalam laporan tahunan.

Hasil penelitian ini konsisten dengan penelitian yang dilakukan Setianto \& Purwanto (2014), Whiting \& Miller (2008) dan Ferreira et al. (2012). Menurut Whiting \& Miller (2008), perusahaan sebagai penyedia informasi tidak berusaha secara penuh untuk melaporkan modal intelektual yang dimilikinya secara eksternal. Dengan demikian, meskipun modal intelektual yang dimiliki oleh perusahaan lebih banyak dibandingkan dengan perusahaan lain bukan berarti akan mengungkapkan modal intelektual secara lebih luas. Hal ini dikarenakan pengungkapan modal intelektual secara lebih luas tidak memberikan keuntungan bagi perusahaan yang memiliki tingkat modal intelektual yang signifikan.

Hasil berbeda dengan penelitian yang dilakukan oleh Purnomosidhi (2006), Utama \& Khafid (2015) yang menyatakan bahwa tingkat modal intelektual berpengaruh negatif terhadap pengungkapan modal intelektual. Utama \& Khafid (2015) menyatakan bahwa ketika manajemen merasakan posisi modal intelektualnya terlalu tinggi, kondisi ini dapat 
berpotensi menimbulkan dampak negatif karena dapat memberi isyarat kepada para pesaing tentang keunggulan dan peluang bisnis yang diperoleh perusahan. Salah satu cara untuk mengantisipasi hal tersebut adalah manajer berupaya mengurangi informasi dalam pengungkapan modal intelektual perusahaan.

\section{Komisaris Independen Memoderasi}

Pengaruh Ukuran Perusahaan terhadap Pengungkapan Modal Intelektual

Hasil uji hipotesis menunjukkan bahwa secara statistik komisaris independen belum mampu untuk memoderasi secara positif

pengaruh ukuran perusahaan terhadap pengungkapan modal intelektual, sehingga dapat disimpulkan bahwa $\mathrm{H}_{3}$ ditolak. Hal ini berarti bahwa pengaruh langsung ukuran perusahaan terhadap pengungkapan modal intelektual akan diperlemah ketika terdapat variabel lain yaitu komisaris independen. Artinya ketika ukuran suatu perusahaan besar, belum tentu komisaris independen dalam perusahaan tersebut banyak dan mampu untuk bekerja secara efektif dalam meningkatkan pengungkapan modal intelektual.

Hasil penelitian ini tidak sejalan dengan agency theory, yang menyatakan bahwa semakin besar ukuran perusahaan diikuti dengan proporsi komisaris independen yang tinggi, maka akan memiliki kontrol kuat atas keputusan manajerial, karena komisaris independen memiliki intensif untuk melakukan pengendalian atas keputusan mereka guna tetap mempertahankan citra yang baik bagi sumber modal dari luar perusahaan.
Ketika ukuran perusahaan semakin besar dan proporsi komisaris independen semakin tinggi, maka pihak manajemen perusahaan merasa kinerjanya akan semakin terawasi, sehingga termotivasi untuk melakukan pengungkapan sukarela terkait modal intelektual dalam laporan tahunan guna mengurangi adanya agency cost.

$$
\text { Menurut Fama \& Jensen (1983) }
$$

keindependensian dewan komisaris yang diproksi dengan proporsi komisaris independen meningkat maka fungsi kontrol akan semakin meningkat, sehingga membuat kontrol atas pengelolaan yang lebih efektif, dan menekan agency cost yang dikeluarkan oleh principal. Salah satu bentuk pengendalian komisaris independen adalah meminta pengungkapan mengenai intellectual capital yang mencukupi dari pihak manajemen, sehingga perusahaan dapat tetap mempertahankan citranya dimata calon investor.

Komisaris independen dalam perusahaan besar belum dapat menyadari bahwa aset terbesar untuk mempertahankan perusahaan mereka adalah dengan menciptakan dan mengembangkan modal intelektual (Mahardika, Khafid, \& Agustina, 2014). Komisaris independen belum menyadari akan pentingnya modal intelektual, meskipun perusahaan tersebut termasuk dalam ukuran yang besar. Perusahaan tersebut mampu memaksimalkan modal intelektualnya dalam jumlah sedikit. Perusahaan besar merupakan entitas yang banyak disorot oleh pasar maupun publik secara umum. Selain itu perusahaan yang mempunyai proporsi 
komisaris independen besar tidak menjamin terwakilinya kepentingan pemegang saham minoritas sehingga fungsi monitoring dan internal control manajemen tingkat atas yang diharapkan tidak berjalan dengan baik. Hasil penelitian ini mendukung penjelasan yang telah ada bahwa belum efektifnya fungsi komisaris independen dalam perusahaan sebagai alat monitor dikarenakan pengangkatan komisaris independen hanya untuk memenuhi aturan corporate governance saja, tidak untuk

menegakkan corporate governance

(Rachmawati 2009).

Uraian di atas menjelaskan bahwa peningkatan pengungkapan modal intelektual tidak bergantung pada peningkatan ukuran perusahaan dengan dimoderasi komisaris independen. Komisaris independen tidak mampu menjadi penentu untuk meningkatnya atau menurunnya pengungkapan modal intelektual yang dipengaruhi oleh komisaris independen. Pengujian hipotesis secara empiris menjelaskan bahwa pengaruh ukuran perusahaan terhadap pengungkapan modal intelektual yang dimoderasi komisaris independen tidak terbukti.

\section{Komisaris Independen Memoderasi Pengaruh}

\section{Tingkat Modal Intelektual terhadap}

\section{Pengungkapan Modal Intelektual}

Hasil uji hipotesis menunjukkan bahwa secara statistik komisaris independen mampu memoderasi pengaruh tingkat modal intelektual terhadap pengungkapan modal intelektual, sehingga dapat disimpulkan bahwa $\mathrm{H}_{4}$ diterima. Hal ini berarti bahwa komisaris independen dapat memperkuat pengaruh tingkat modal intelektual terhadap pengungkapan modal intelektual. Artinya tingkat modal intelektual dengan dimoderasi oleh komisaris independen mampu memprediksi perilaku variabel pengungkapan modal intelektual. Ketika tingkat modal intelektual yang dimiliki oleh perusahaan tinggi didukung oleh proporsi komisaris independen yang tinggi, maka pengungkapan modal intelektual akan meningkat.

Hasil tersebut sesuai dengan teori yang diajukan yaitu signalling theory. Teori sinyal menjelaskan bahwa perusahaan yang memiliki kinerja baik akan menggunakan informasi yang dimilikinya untuk memberikan sinyal positif ke stakeholder. Perusahaan dengan tingkat modal intelektual yang tinggi akan cenderung memberikan sinyal positif salah satunya dengan cara melakukan pengungkapan informasi secara menyeluruh. Kondisi tersebut akan diperkuat ketika terdapat faktor lain, yaitu komisaris independen sebagai pihak independen di perusahaaan yang memiliki kewenangan untuk mengawasi dan memberi nasehat kepada pihak manajemen perusahaan.

Teori stakeholder menyatakan pemegang saham memiliki hak untuk mendapatkan informasi tentang aktivitas-aktivtas perusahaan, termasuk aktivitas tentang pengelolaan modal intelektual. Dengan demikian, perusahaan dengan tingkat modal intelektualnya cukup signifikan akan termotivasi untuk melakukan pengungkapan modal intelektualnya secara lebih luas untuk memuaskan kepentingan pemegang saham dan stakeholders lainnya. Pengungkapan tingkat modal intelektual yang dilakukan oleh

DOI: doi.org/10.21009/wahana-akuntansi/13.2.01 
perusahaan tidak lepas dari pengaruh komisaris independen dimana kinerja manajer suatu perusahaan akan selalu diawasi oleh pihak komisaris independen, selaku wakil dari pemegang saham.

Berdasarkan hasil dan uraian diatas, dapat ditarik kesimpulan bahwa semakin besar ukuran perusahaan diikuti dengan semakin banyak jumlah komisaris independen dalam suatu perusahaan, maka tingkat modal intelektual yang diungkapkan oleh perusahaan, sehingga dapat dikatakan komisaris independen mampu memoderasi secara positif signifikan pengaruh ukuran perusahaan terhadap pengungkapan modal intelektual.

\section{KESIMPULAN}

Berdasarkan analisis data dan pembahasan, maka dapat ditarik kesimpulan bahwa pengujian parsial menunjukkan ukuran perusahaan berpengaruh positif signifikan terhadap pengungkapan modal intelektual, tingkat modal intelektual tidak berpengaruh terhadap pengungkapan modal intelektual, komisaris

independen memoderasi secara negatif signifikan (memperlemah) pengaruh ukuran perusahaan terhadap pengungkapan modal intelektual dan mampu memoderasi positif signifikan (memperkuat) pengaruh tingkat modal intelektual terhadap pengungkapan modal intelektual. Saran bagi perusahaan perbankan untuk melakukan pengungkapan modal intelektual yang lebih ketika memiliki tingkat modal intelektual yang tinggi. Hal tersebut dinilai menjadi salah satu sinyal yang baik bagi stakeholders sehingga para investor akan tertarik untuk menanamkan saham di perusahaan. Bagi penelitian selanjutnya, disarankan menambahkan periode penelitian untuk mendapatkan hasil penelitian yang lebih akurat.

\section{DAFTAR PUSTAKA}

Ashari, P. M. S., \& Putra, I. N. W. A. (2016). Pengaruh Umur Perusahaan, Ukuran Perusahaan, Profitabilitas, Leverage dan Komisaris Independen Terhadap Pengungkapan Modal Intelektual. E-Jurnal Akuntansi Universitas Udayana, 14(3), 1699-1726.

Assety, N. A., \& Suhardianto, N. (2016). Item Pengungkapan Intellectual Capital Disclosure (pp. 1-18).

Benevene, P., et.al. (2017). Representation of Intellectual Capital's Components Amongst Italian Social Enterprises. Journal of Intellectual Capital, 18(3), 564-587.

Bozzolan, S., Favotto, F., \& Ricceri, F. (2003). Italian Annual Intellectual Capital Disclosure. Journal of Intellectual Capital, 4(4), 543-558.

Bronzetti, G., \& Veltri, S. (2013). Intellectual Capital Reporting in the Italian Non-profit Sector: Analysing a Case Study. Journal of Intellectual Capital, 14(2), 246-263.

Bruggen, A., Vergauwen, P., \& Dao, M. (2009). Determinants of Intellectual Capital Disclosure: Evidence from Australia. In Management Decision (Vol. 47, pp. 233245).

Deegan, C. (2004). Environmental Disclosures and Share Prices - A Discussion about Efforts to Study this Relationship. Accounting Forum, 28(1), 87-97.

Fama, E. F., \& Jensen, M. C. (1983). Separation of Ownership and Control*. Journal of Law and Economics, 26(2), 301-325. 
Ferreira, A. L., Branco, M. C., \& Moreira, J. A. (2012). Factors Influencing Intellectual Capital Disclosure by Portuguese Companies. International Journal of Accounting and Financial Reporting, 2(2), 278-298.

Firer, Steven., \& Williams, S. M. (2003). Intellectual Capital and Traditional Measures of Corporate Performance. Journal of Intellectual Capital, 4(3), 348360.

Iswanti, S. (2007). Memprediksi Kinerja Keuangan dengan Modal Intelektual pada Perusahaan Perbankan Terbuka DI BURSA EFEK JAKARTA. Jurnal Akuntansi, 11(2), 159-174.

Kamath, G. B. (2007). The Intellectual Capital Performance of the Indian Banking Sector. Journal of Intellectual Capital, 8(1), 96123.

Kang, H. H., \& Gray, S. J. (2011). Reporting intangible assets: Voluntary disclosure practices of top emerging market companies. The International Journal of Accounting, 46, 402-423.

Kubo, I., \& Saka, A. (2002). An Inquiry into the Motivations of Knowledge Workers in the Japanese Financial Industry. Journal of Knowledge Management, 6(3), 262-271.

Mahardika, E. S. S., Khafid, M., \& Agustina, L. (2014). Pengaruh Struktur Kepemilikan, Ukuran dan Umur Perusahaan terhadap Kinerja Intellectual Capital. Accounting Analysis Journal, 3(1), 100-108.

Mondal, A., \& Ghosh, S. K. (2014). Determinants of Intellectual Capital Disclosure Practices of Indian Companies, 3(3), 25-36.

Nugroho, A. (2012). Faktor-faktor yang Mempengaruhi Intellectual Capital Disclosure (ICD), 1(2), 1-6.
Oktavianti, H. (2014). Faktor-Faktor yang Mempengaruhi Pengungkapan Intellectual Capital. Jurnal Ilmu \& Riset Akuntansi, 3 (9), 1-19.

Ousama, A. A., Fatima, A. H., \& Majdi, A. R. H. (2012). Determinants of Intellectual Capital Reporting. Journal of Accounting in Emerging Economies, 2(2), 119-139.

Petty, R., \& Guthrie, J. (2000). Intellectual Capital Literature Review: Measurement, Reporting and Management. Journal of Intellectual Capital, 1(2), 155-176.

Priyanti, S. Y., \& Wahyudin, A. (2015). Determinan Pengungkapan Modal Intelektual berdasarkan Variabel Keuangan dan Non Keuangan, 4(2), 1-10.

Purnomosidhi, B. (2006). Pengungkapan Suka Rela Modal Intelektual pada Perusahaan Publik di BEJ, 1-21.

Saendy, G. A., \& Anisykurlillah, I. (2015). Pengaruh Good Corporate Governance, Kinerja Keuangan, Modal Intelektual terhadap Pengungkapan Modal Intelektual. Accounting Analysis Journal, 4(3), 1-10.

Setianto, A., \& Purwanto, A. (2014). Analisis Faktor-Faktor Yang Mempengaruhi Pengungkapan Modal Intelektual ( Studi Empiris pada Perusahaan yang Terdaftar di “Indeks Kompas 100 ” Tahun 2010-2012). Diponegoro Journal of Accounting, 3(4), 115.

Suwarjuwono, T., \& Kadir, A. P. (2003). Intellectual Capital: Perlakuan, Pengukuran dan Pelaporan (Sebuah Library Research). Jurnal Akuntansi dan Keuangan, 5(1), 3557.

Utama, P., \& Khafid, M. (2014). Faktor-faktor yang Mempengaruhi Luas Pengungkapan Modal Intelektual pada Perusahaan Perbankan di BEI. Accounting Analysis Journal, 3(1), 361-369. 
Whiting, R. H., \& Miller, J. C. (2008). Voluntary Disclosure of Intellectual Capital in New Zealand Annual Reports and the "Hidden Value." Journal of Human Resource Costing \& Accounting, 12(1), 2650.

Widhianningrum, P., \& Amah, N. (2012). Pengaruh Mekanisme Good Corporate Governance terhadap KInerja Keuangan Selama Krisis KeuanganTahun 2007-2009. Jurnal Dinamika Akutansi, 4(2), 1-9.

Widowati, E. H., Sumarta, N. H., \& Pradono, N. S. H. (2016). Management Background, Intellectual Capital and The Financial Performance of Indonesian Banking. Jurnal Dinamika Akuntansi, 8(2), 161-170.

Yi, A., \& Davey, H. (2010). Intellectual Capital Disclosure in Chinese (Mainland) Companies. Journal of Intellectual Capital, 11(3), 326-347.

Zulkarnaen, E. I. (2013). Good Corporate Governance terhadap Luas Pengungkapan Intellectual Capital. Jurnal Dinamika Akuntansi, 5(1), 79-85. 